Journal of African Real Estate Research
Volume 6, Issue 1
Special Issue: Women in African Real Estate and Urban
Development Research

\title{
Barriers to Housing Development in Lagos Fringe Areas: A Developer's Perspective
}

Esther O. Thontteh ${ }^{1}$ and Modupe M. Omirin ${ }^{2}$

${ }^{1-2}$ University of Lagos, Nigeria

To cite this article: Thontteh, E. O. \& Omirin, M.M. (2021). Barriers to Housing Development in Lagos Fringe Areas: A Developer's Perspective. Journal of African Real Estate Research, 6(1), pp.63-88. DOI: 10.15641/jarer.v6i1.955.

\begin{abstract}
This study investigates developers' land acquisition and housing developments to assess factors that influence utilisation of the acquired land for housing development and strategic approaches that could drive mass housing developments. A sample of 141 members of the Real Estate Developers Association of Nigeria (REDAN) and 31 heads of units in the Land Bureau were surveyed. Weighted mean score and factor analysis were used to identify the barriers limiting housing developments and strategies that could enhance developers' housing initiatives. Findings revealed that the total number of housing units developed is insignificant in the study location, and eight groups of barriers were identified by developers as limiting their housing initiatives. Weak land institutional frameworks and inconsistency in government regulations and policy were recurring themes. These barriers are germane to housing development in the urban fringe of a growing African mega-city that needs 500,000 new housing units annually for the next 10 years to bridge the housing gap. The study recommends an efficient land reform framework to remove policies and regulations that impede timely land documentation, administration and housing development and to include developers through cooperative ventures.
\end{abstract}

Keywords: Developer; Housing; Land Acquisition; Land Policy; Urban Fringe; Nigeria

\section{Introduction}

The Nigerian National Housing Policy of 2002 aimed to create an enabling environment for land accessibility to boost housing construction by organised private developers. The policy encouraged land acquisitions by developers, especially in the Lagos fringe areas, in anticipation of development of housing units to bridge the gap between housing need and supply. Despite this, the housing deficit in Lagos has persisted. In fact, it was estimated 500,000 new

\footnotetext{
${ }^{1}$ ethontteh@gmail.com
} 
units would be required per annum for the next 10 years to bridge this gap (Alufohai, 2013). Reports have shown that subsequent efforts have not been able to match the required estimate. For instance, in 2015, only 940 housing units were delivered through the joint effort of government and private developers (Aliu et al., 2017; Babalola et al., 2020). This is a major cause for concern with continuous population growth at $3.2 \%$ per annum and a rapid urbanisation rate exceeding the average for most developing countries. The United Nations Department of Economic and Social Affairs-UNDESA (2019) projects that while the world's urban population will grow at a rate of $1.2 \%$ annually from 2015 to 2025 , the annual rate of growth in developing countries is estimated to be twice that at $2.5 \%$. With an average population density of 20,000 persons per square kilometre, the crowding in Lagos is dire and requires immediate analysis and intervention as attested to in extant literature (Iyanda, 2015; Olofa \& Nwosu, 2015; Adedire et al., 2016; Hsieh \& Moretti, 2017; De Maria, 2019).

Acquisition of parcels of land without immediate development often occurs in and around urban settlements. Large expanses of land in the Lagos fringe area are left unused for several years even though there is a need for immediate housing construction. The current expansion and intense competition for land by individuals and private housing developers, especially along major transportation routes in the Lagos fringe areas, accentuates the need for urgent attention especially because there is a paucity of research on organised private developers' activities and their impact on housing supply in the study area.

The land acquisition process in the Lagos fringe area involves several stages before development (Nubi, 2001; Olofa \& Nwosu, 2015), including land identification, negotiation, procurement and documentation. Land identification involves the search for information by the prospective purchaser or intermediaries who mediate or facilitate the negotiation process. Once the developer's interest in land has been established, negotiations involving local communities or customary right holders start. This usually involves critical debate among villagers and local representatives as to the benefits of the project to the immediate community. Payment for the land and compensation to persons negatively affected is the next stage. The mode and distribution of payments over a specific period of time are specified. Compensation could be paid in physical infrastructure or cash. Land is allocated after payment is complete. Documentation is the next stage. The State Government's Land Bureau is the formal agency responsible for ratifying transactions involving land held under customary ownership especially large parcels of land. The sale/purchase agreement signed by both parties and the receipt issued by the land-owning family are then taken to the Land Bureau for further processing to obtain the Certificate of Occupancy (C of $\mathrm{O}$ ) (the most highly rated and acceptable form of title to land), or Governor's Consent (GCT) in the case of land already held under a valid right of occupancy. Only after this process is completed should actual construction commence. Despite the sequential process, many developers still experience threats to their possession of the land from the regulatory agency. 
The reasons for the slow pace of construction, especially of housing units, after successful acquisition of land by developers is yet to be empirically established. In particular, it is essential to investigate the extent to which developers' land acquisitions impact the housing supply in the Lagos metropolis fringe and to establish reasons why housing supply expectations are not being met. Previous studies, including Adisa (2020), Olmedo and Ward (2016), and Hull and McGroarty (2014), disclosed that residential development for middle- and low-income workers across cities has shifted from major centres and their immediate neighbourhoods to fringe areas. A cursory evaluation suggests that Lagos is no exception - a megacity with an unrelenting rapid increase in population in the fringe areas far exceeding that in the inner core areas. Apart from high rents driving residents to the fringe, a probable accentuating factor is the 'new normal' of working from home due to social distancing regulations introduced to curb the spread of the COVID19 pandemic. Most workers can now stay away from the city to work from the comfort of their homes. This notwithstanding, the rate of new housing construction is far below what is required.

\subsection{The Research Questions}

This study, therefore, seeks to explicate the growing housing deficit despite land acquisitions in the periphery. Specifically, the study seeks to establish why organised formal developers engage in extensive land acquisition without significantly developing housing despite the need to alleviate the growing deficit. The objectives of the study are:

- to establish the extent of developers' land acquisitions,

- to determine barriers that hinder the development of housing units on the land acquired, and

- to identify strategies that could encourage increased housing development on the land acquired.

\section{Literature Review}

A range of supply-side interventions in the Nigerian housing sector have been used in recent years to boost housing production through direct construction, renovation of existing residential units and public-private partnership programs. Efforts have also been directed at increasing the ability of housing supply to better respond to changes in demand (Nubi, 2001; Akinyode \& Tareef, 2014). However, housing need far exceeds the supply (Morakinyo et al., 2015; Nubi 2015). Advocacy for private sector housing delivery that began about two decades ago has increased developers' land acquisition activities without achieving the anticipated improvement in housing development. This, in the face of resource scarcity concerns, according to Manda et al. (2019), has only made the government's lapses in its relationship with investors/developers and the local population more visible.

The National Housing Policy was introduced to promote a shift in emphasis to the organised private sector as the main engine for housing delivery in 
Nigeria. The key features of this policy include placing the private sector in a pivotal position for the delivery of affordable houses on a sustainable basis. The government was assigned the responsibility of providing primary infrastructure for new real estate developments. It was to review and amend the Land Use Act to ensure better access to land and speedier registration and assignment of titles to developers. Another feature of the policy is the restructuring of the mortgage system such that the Federal Mortgage Bank of Nigeria (FMBN) became the apex bank disbursing funds to primary mortgage institutions that would lend to individuals and corporate housing developers. A National Housing Fund (NHF) was established and mandatory deposits of a portion of civil servants' salaries instituted, among other steps, to facilitate accumulation of funds. In addition, more favourable mortgage terms were introduced, along with a five-year tax holiday incentive for developers. Although such incentives had been advocated before by Onibokun (1990), Mabogunje (1993) and Agbola (1993), it was only under this policy that the incentives were made operational (IMF, 2015; Olofa \& Nwosu, 2015; Usoro, 2015; Nwoko, 2016). Further reforms include support for the Building Materials Producers Association of Nigeria (BUMPAN) and the establishment of the Real Estate Developers Association of Nigeria (REDAN) to organise the stakeholders and assist the private sector to play the leading role in housing production and delivery. Furthermore, interest rates were substantially reduced on National Housing Fund (NHF) loans to REDAN members and the housing finance sub-sector was restructured to include the introduction of the secondary mortgage market (Adelekan, 2013). REDAN is now the principal agency of the organised private sector recognised by the government and approved by FMBN for housing development. Subsequently, the National Housing Policy encouraged land acquisitions by developers, especially in the Lagos fringe areas, in anticipation of profits from the development of housing units.

Many researchers have attempted pragmatic, policy-oriented and scientific research on housing related issues in Nigeria; however, very few have focused on land acquisition matters with only tangential reference to developers and related issues in the fringe areas. Some of the studies concentrated mainly on housing needs and some on the evaluation of the policy and emanating programmes while others investigated housing finance, housing construction and related administrative matters. Chatterjee (1981), Agbola (1993), Ogu and Ogbuozobe (2001) analysed problems that work against increasing the supply of housing units in Nigeria and asserted that predominance of small firms, inadequate workforce, institutional inefficiencies, organisational inefficiencies and inadequate housing policy implementation framework are major issues that affect housing development. The findings of these studies are still relevant as these problems persist after 40 years (Akeju, 2007; Aliu et al., 2017; Adedire, 2018) In contrast, Omirin (1992) affirmed that access to land was a major constraint 30 years ago, but it was no longer as serious as housing finance which later became the focus of extensive analysis by Nubi (2000). Further, Ademiluyi, and Bashiru (2008) studied public and private developers as agents in urban housing delivery in Lagos State. They found that labour cost was one of the major obstacles to 
developers delivering housing. The fringe area was rarely considered in its entirety in these studies, although some sought to comprehensively clarify the relationship between the quantity of land acquired and housing supply (Agbola, 1993; Adelekan, 2013; Nubi, 2015). This remains a question worthy of in-depth investigation as an area with ever increasing need for housing deficit reduction.

\subsection{The Urban Fringe Dynamics and Rationale for the Study}

Generally, fringe areas are characterised by rapid development and transition from agricultural land use to semi urban and urban uses (Mori, 1998). In developing countries, the transition is largely unplanned. As a result, fringe areas are susceptible to sprawl with its attendant negative effects. Also, urban fringe areas are subject to many competing interests and, as such, can be analysed from different perspectives. In the international planning literature, urban fringe areas often evoke a concern with sprawl (Gallent, 2006; Feng et al., 2015; SACN, 2018). Some of these studies allude to the potential of properly implemented housing policy to mitigate the negative effects of urban sprawl, resolve housing shortages, promote transit-oriented development and ensure orderly expansion in the long run. The fringe area requires an institutional framework to strike a balance between relieving poverty, protecting the environment, maximising the productivity of human and natural resources, promoting efficiency of the property market and ensuring synergy between urban and rural areas (Heimlich \& Anderson, 2001; Allen, 2003; Saxena \& Vyas, 2019a; Adisa, 2020).

Mabogunje (2007) and Adedayo (2014) affirmed that because of population growth, expansion will continue to extend towards several previously standalone peripheral towns especially in the north of Lagos State, which belongs to another administrative jurisdiction; Ogun State. The fringe area is often an area that spans more than one administrative unit. As a result, it will have weak links and limited municipal powers in sectors such as transportation and land use planning. This is true to a large extent of Lagos, which is continuously expanding its built-up area and encroaching upon parts of the territories of Ogun State.

The problems associated with fringe development are not unique to Lagos. The UK Department for Communities and Local Government reports that new build completion was used to control incompatible land uses and bridge the gap for housing shortfalls in its fringe areas (Gant et al., 2011). Accordingly, Saxena and Vyas (2019b) noted weak government regulations, which manifest in the form of sprawled development, informal and illegal structures, as one of the major barriers in fringe areas. A lack of sufficient housing stock is common throughout Sub-Saharan Africa due to rapid population urbanisation and a shortage of housing construction (World Bank, 2015). Many households cannot afford basic formal housing or access mortgage loans due to the cost and/or cumbersome regulatory requirements. The key challenge for African cities is that the formal channels through which quality housing is produced and financed face major constraints that limit 
access for a large share of urban households. A recent United Nations study found that formal housing investment lags behind urbanisation by nine years in Africa (Dasgupta et al., 2014). The experience in Sub-Saharan Africa shows there are many factors besetting housing construction that require policy interventions.

\subsection{Theoretical Underpinnings}

Formal housing supply is the product of a complex decision-making process involving organised private developers, landowners, financiers and government agencies. There is very little evidence about how each participant reacts to others in the process. This suggests the application of game theory to explain developers' rationalisation in the study location. Developers cannot perform any of their roles in isolation. For example, they are reliant on landowners for the supply of land, the town planning authority for permission to develop, financiers for capital, and consumers to complete their cash flow cycle. Moreover, at all stages in the process, they are dependent upon a multiplicity of groups and individuals to supply information for decision making and to reach their development goals. According to Anglin and Arnott (1991), Samsura et al. (2010) and Sengupta (2013), game theory focuses on analyzing the outcome of strategic interaction among stakeholders and the implications of those outcomes.

Land transactions during land use change have been studied by HoltslagBroekhof et al. (2014) and Zhang and Skitmore (2015) using game theory. The theory builds on the assumption that decision-making is an interactive process that relies on three basic concepts: the players- referring to the developers making a decision; strategies- referring to developers' actions; and pay offs-referring to the value that the result of a decision gives. In addition, there are three agents who determine the development decision model. These are: (i) the developers who initiate development plans, (ii) the government institution charged with approval of such plans and (iii) the public, whose demand for residential accommodation drives development (Maruani \& Amit-Cohen, 2011). Subsequently, the outcomes of the interaction among the three agents seemingly determine the attributes of the fringe areas as well as the quantity of housing supplied to the market.

The interaction among stakeholders in the housing market has been characterised by the role of each actor and contribution to the process in terms of leadership, strategies and dominance. Ball (2003) also applied game theory to a study that focused on the strategic interactions of land developers to analyze the decisions made by two independent land developers on price and quality. The findings showed that the decentralised developer can adopt two kinds of strategies depending on the distance and the anticipated level of quality at the CBD. Therefore, an interdependent decision-making process in which the decision-makers involved have conflicting preferences and the outcomes of their decisions cannot be determined by one party or actor is only explicable applying game theory. Because game theory focuses on situations in which interactions and interdependency play a role, there is a growing 
literature that applies game theory to the housing market. It is believed that this can provide an important theoretical basis for explaining the housing development processes and suggesting some clues to future empirical work on this theme.

This study examines the actions of two classes of agents (developers and Land Bureau officials with the responsibility of regulation and policy making), the strategies adopted in the process of land acquisition and housing development in the fringe area of Lagos by the parties and the outcome of the strategies adopted. The research aimed principally to gain a deeper understanding of the constraints affecting physical housing construction by developers in the Lagos fringe areas. The section below provides the data collected on developers' actions and strategies and the government agency's reactions to the strategies adopted to enhance housing development in the study area. The resultant effects on the quantity of housing construction are derived and analyzed further to expose the barriers to developers' efforts in housing development and evaluate the applicability of strategies that will be workable and acceptable to the actors in the study location to encourage development.

\section{Methodology}

Secondary data were gathered from documents in government archives, relevant published materials and internet sources. Primary data were obtained through a semi-structured questionnaire and a structured interview schedule. A questionnaire was administered to a sample of REDAN members who are mainly professionals in the built environment and other allied professions while in-depth structured interviews were conducted with government officials, including planners, land surveyors, estate surveyors, architects, and lawyers. The questionnaire was designed to provide responses to specific questions about land acquisition and housing development and was administered by the researcher, assisted by two trained research assistants, between January and March 2019.

The study adopted the survey approach to elicit information on developers' land acquisition and housing development constraints in the study area. Identifying the quantity of housing stock (formal and informal) and developers' contribution to the housing stock in the study area is difficult to quantify in the absence of consistent and reliable data. This work relies on development titles obtained by the developers (C of O or GCT) to estimate their contribution to the housing stock in the study area. This approach was chosen for this study based on the research objectives posited to explain the extent of land acquisition and strategies adopted in housing development. The purposive approach allows investigators to retain the holistic and meaningful characteristics of real-life events such as small group behaviour, organisation, and neighbourhood interaction (Yin, 2011). A purposive sampling technique was adopted because the focus of the study demands concentration on the interaction of individuals or groups involved in the key activities under investigation. 


\subsection{Sample}

The population for the study is made up of members of REDAN and the heads of units in various departments of the Land Bureau in Lagos and Ogun States. REDAN's membership in Lagos (southwest zone) is 251 and there are 31 Land Bureau officers. Only 141 REDAN members were in practice with offices within Lagos fringe areas, which formed the sample of developers for the study. A total of 123 questionnaires were completed for a response rate of $87.23 \%$; however, due to incomplete answers on some questionnaires, only 109 are used in the analysis for a usable response rate of $77.30 \%$.

The study set out to interview all 31 heads of Land Bureau units relevant to the study. Where the heads of units were not available, the researchers proceeded to contact each subsequent person in the hierarchy until an official agreed to participate and then gathered data using a structured interview format.

\subsubsection{Characteristics of Respondents-Developers}

The characteristics of the 109 REDAN members whose questionnaire responses were analysed are shown in Table 1. A few had been working in the industry since 1992; however, the developers had been in the real estate business, on average, for 12 years. This is long enough to give reliable insight into the subject matter. The majority of their firms $(58.72 \%)$ are corporations. The average staff size is 12 ; however, $24.77 \%$ work in firms with more than 20 staff members of varied technical skills and qualifications. This is significant as it shows that they have requisite manpower to embark on housing development projects. However, only $17.43 \%$ indicated their organisations' financial strength to be above 250 million (US\$694,444). Although this is rather small, it must be borne in mind that they use a range of modes of financing their projects.

Table 1: Land Developer Respondents' Characteristics

\begin{tabular}{|l|l|c|}
\hline Variable & \multicolumn{1}{|c|}{ Category } & $\begin{array}{c}\text { Percentage } \\
(\mathbf{n = 1 0 9 )}\end{array}$ \\
\hline \multirow{3}{*}{ Gender } & Male & $84.40 \%$ \\
Qducational & Female & $15.60 \%$ \\
\hline & Ordinary National Diploma & $2.75 \%$ \\
& Higher National Diploma & $12.84 \%$ \\
& BSc & $38.53 \%$ \\
& MSc & $42.20 \%$ \\
& M.Phil/PhD & $3.67 \%$ \\
\hline & Estate Surveyor and Valuer & $33.94 \%$ \\
& Civil Engineer & $11.93 \%$ \\
& Architect & $11.01 \%$ \\
& Builder & $10.09 \%$ \\
& Urban Planner & $3.67 \%$ \\
& Land Surveyor & $2.75 \%$ \\
& Quantity Surveyor & $1.83 \%$ \\
& Other & $24.77 \%$ \\
& (Lawyer/Marketer/Accountant/Geologist) & \\
\hline
\end{tabular}


Special Issue: Women in African Real Estate and Urban Development Research

\begin{tabular}{|l|l|c|}
\hline \multirow{3}{*}{ Professional } & Probationer & $15.60 \%$ \\
& Associate & $44.95 \%$ \\
& Fellow & $14.68 \%$ \\
& Other & $24.77 \%$ \\
\hline \multirow{4}{*}{ Organisational form } & Corporate Organisation & $58.72 \%$ \\
& Sole Proprietorship & $28.44 \%$ \\
& Private Individual & $11.01 \%$ \\
& Partnership & $1.83 \%$ \\
\hline \multirow{4}{*}{ Year of Establishment } & $1992-1996$ & $22.02 \%$ \\
& $1997-2001$ & $19.27 \%$ \\
& $2002-2006$ & $11.93 \%$ \\
Organisation's Staff & $2007-2011$ & $22.02 \%$ \\
Size & $2012-2018$ & $24.77 \%$ \\
\hline \multirow{3}{*}{ Mode of Project } & $1-5$ & $22.02 \%$ \\
Funding & $6-10$ & $19.27 \%$ \\
& $11-15$ & $11.93 \%$ \\
& $16-20$ & $22.02 \%$ \\
& More then 20 & $24.77 \%$ \\
\hline Organisation's & Bank Loan & $41.28 \%$ \\
Financial Strength (¥) & Public Sector Contribution & $20.18 \%$ \\
& Off Plan Payment/Joint & $1.83 \%$ \\
& Venture/Stakeholders Fund & $36.70 \%$ \\
\hline & Less than 50 million & $30.28 \%$ \\
& 101-100 million & $16.51 \%$ \\
& $151-200$ million & $3.67 \%$ \\
& $201-250$ million & $8.26 \%$ \\
& More than 250 million & $23.85 \%$ \\
\hline
\end{tabular}

Note: US\$1 = 360.00 NGR Naira (\#) as of $7^{\text {th }}$ May, 2019.

\subsubsection{Characteristics of Respondents - Land Bureau Officers}

The Land Bureau officers interviewed have 7 years of experience, on average. This is long enough for them to understand the dynamics of land acquisition and titling issues as well as the strategies required for progression and ease of doing business for both investors and developers. Their professional qualifications, as shown in Table 2, indicate that they have the requisite professional experience.

Table 2: Land Bureau Officers Respondents' Characteristics

\begin{tabular}{|l|l|c|}
\hline Variable & \multicolumn{1}{|c|}{ Category } & Percentage (n=31) \\
\hline \multirow{5}{*}{ Department } & Land Services/Land Bureau & $67.74 \%$ \\
& Town Planning & $22.58 \%$ \\
& Administrative & $9.68 \%$ \\
\hline \multirow{5}{*}{ Educational Qualification } & Higher National Diploma & $35.48 \%$ \\
& BSc & $29.03 \%$ \\
& MSc & $32.26 \%$ \\
& M.Phil./PhD & $3.23 \%$ \\
\hline \multirow{5}{*}{ Discipline/Profession } & Estate Surveyor and Valuer & $32.26 \%$ \\
& Urban Planner & $25.81 \%$ \\
& Quantity Surveyor & $6.45 \%$ \\
& Architect & $3.23 \%$ \\
& Others (Admin officer) & $32.26 \%$ \\
\hline
\end{tabular}




\begin{tabular}{|l|l|c|}
\hline \multirow{5}{*}{ Professional Qualification } & Probationer & $25.81 \%$ \\
& Associate & $58.06 \%$ \\
& Fellow & $6.45 \%$ \\
& Other & $9.68 \%$ \\
\hline \multirow{5}{*}{ Experience } & Less than 1 yr & $3.23 \%$ \\
& $1-3$ yrs & $6.45 \%$ \\
& $4-6$ yrs & $41.94 \%$ \\
& $7-9$ yrs & $22.58 \%$ \\
& 10 yrs or more & $25.81 \%$ \\
\hline
\end{tabular}

\subsection{Survey Instrument and Analysis Tools}

The questionnaire administered to the REDAN sample contained both open and closed-ended questions- the latter for ease of analysis and the former to give the respondents opportunity to clarify their responses. The questionnaire administered to the Land Bureau officials contained semi-structured questions to give respondents opportunity for clarifications. The instruments showed good face and content validity.

- To address the first research objective, the questionnaire required the developers to indicate the quantity of land acquired at various locations within the study area, the types of title documents obtained, and the quantity of land developed. Simple descriptive statistics were used to determine the proportion of land developed from the total land acquired.

- The second research objective required identifying the major causes of delay in housing development after land acquisition. A total of 28 potential causes were identified from the literature. Developers were asked to indicate the degree of seriousness of the causes using a 5point itemised (Likert) rating scale from 'Very serious' to 'Very unserious'. Items with mean values of 4.0 and above were judged to be the most prominent influences hindering immediate housing development in the study locations. Furthermore, factor analysis employing the principal component method was applied to identify the groups of barriers causing delay in housing development in the Lagos fringe area.

- The third objective was pursued from two perspectives. Having identified the barriers affecting housing development, developers were further asked to indicate their preferred strategy for boosting housing development by ranking the identified strategies from the literature using a Likert scale of 1 to 5, where 5 means 'Very acceptable' and 1, 'Very unacceptable'. A weighted mean value greater than 4.0 is interpreted as the respondents accept that if adopted, that strategy will enhance housing development. Government officials in the Land Bureau were then interviewed to determine if there is similarity or mismatch between strategies they adopt and those preferred by the developers to assist in the identification of strategies needed to enhance the rate of development of housing units on the land acquired. The Land Bureau officers were asked to rate the extent to which collaborative strategies are being 
used to enhance housing development of land acquired in the fringe areas on a scale of 1 to 5 from 'Not in existence' to 'Very often' with a criterion of 4.0 to identify strategies that are more in use.

\section{Results and Analysis}

The study questions were structured to unravel the challenges of housing development in the study area. The results and their analysis are presented below.

\subsection{Extent of Land Acquisition, Title Documents Obtained and Housing Construction in Lagos Fringe Area (2004-2019)}

Table 3 shows the quantity and status of land acquired by developers and the quantity developed in the study area between 2004 and 2019. Only an average of $30 \%$ of the land acquired by developers have C of Os or GCT while $70 \%$ of them have other, less reliable, title documents such as registered survey plans, purchase receipts, evidence of publication in government's gazette, excision letters and deeds of assignment. These latter types of documents are not acceptable to financial institutions for loan disbursements. Most of the land without $\mathrm{C}$ of $\mathrm{O}$ was affirmed to be undeveloped. In general, it is interesting that about the same proportion of the total areas acquired in Lagos as in Ogun state has $\mathrm{C}$ of $\mathrm{O}$. Nevertheless, the government is yet to attain a global best practice by which all land in the state will have titles that are acceptable to financial institutions for development loan purposes.

Table 3: Extent of Land Acquisition and Title Document Obtained in Lagos Fringe Area (2004-2019)

\begin{tabular}{|l|c|c|c|c|c|c|c|c|c|c|c|c|}
\hline \multicolumn{2}{|c|}{} & \multicolumn{9}{|c|}{ Title Document Obtained (Hectares) } \\
\hline Community & $\begin{array}{c}\text { Quantity } \\
\text { Purchased } \\
\text { (Hectares) } \\
\text { 2004-2019 }\end{array}$ & C of O & GCT & DAS & EXC & RCT & SVY & LOA & Nil & $\begin{array}{c}\text { Qty } \\
\text { Dev }\end{array}$ & State \\
\hline \multicolumn{9}{|c|}{} & \multicolumn{7}{|c|}{ Lagos/Ibidan Expressway } \\
\hline Arepo & 53.45 & 22.65 & & 8.8 & & 22.0 & & & & 16.0 & OG \\
\hline Ibafo & 7.2 & 3.2 & & & & 2.0 & 2.0 & & & 0.0 & OG \\
\hline Isheri & 24.0 & 2.0 & & & & 20.0 & 2.0 & & & 0.0 & LA \\
\hline Magboro & 41.2 & 19.6 & & 10.0 & & 0.8 & & 10.8 & 0.8 & 3.2 & OG \\
\hline Mowe & 50.4 & 21.6 & 20.0 & 0.8 & 8.0 & & & & & 2.13 & OG \\
\hline Ofada & 35.6 & & & 20.0 & & 14.0 & 1.6 & & & 0.0 & OG \\
\hline Sagamu & 5.2 & 5.2 & & & & & & & & 0.0 & OG \\
\hline Simawa & 32.1 & 1.0 & & 2.0 & & 22.4 & 6.7 & & & 0.0 & OG \\
\hline Total & $\mathbf{2 4 9 . 1 5}$ & $\mathbf{7 5 . 2 5}$ & $\mathbf{3 0 . 0}$ & $\mathbf{3 1 . 6}$ & $\mathbf{8 . 0}$ & $\mathbf{8 1 . 2}$ & $\mathbf{1 2 . 3}$ & $\mathbf{1 0 . 0}$ & $\mathbf{0 . 8}$ & $\mathbf{2 1 . 3 3}$ & OG \\
\hline \% & & $\mathbf{3 0 . 2}$ & $\mathbf{1 2 . 0 4}$ & $\mathbf{1 2 . 6 8}$ & $\mathbf{3 . 2 1}$ & $\mathbf{3 2 . 5 9}$ & $\mathbf{4 . 9 4}$ & $\mathbf{4 . 0 1}$ & $\mathbf{0 . 3 2}$ & & \\
\hline
\end{tabular}


Special Issue: Women in African Real Estate and Urban Development

Research

\begin{tabular}{|c|c|c|c|c|c|c|c|c|c|c|}
\hline \multicolumn{11}{|c|}{ Lekke-Epe Espressway } \\
\hline Ajah & 89.99 & 60.0 & 6.4 & 35.4 & & & 2.4 & & 7.30 & LA \\
\hline Ibeju-Lekki & 91.2 & 38.33 & 2.87 & & 0.4 & & 33.6 & 16.0 & 6.87 & LA \\
\hline & & 0.8 & & 0.53 & 12.0 & 1.6 & 34.25 & & & \\
\hline Epe- FTZ & 49.18 & & & & & & & & 0.0 & LA \\
\hline Total & 230.37 & 99.13 & 9.27 & 35.93 & 12.4 & 1.6 & 70.25 & 16.0 & 14.17 & \\
\hline$\%$ & & 40.53 & 4.02 & 15.6 & 5.38 & 0.69 & 30.49 & 6.95 & & \\
\hline \multicolumn{11}{|c|}{ Ikorodu } \\
\hline Ikorodu & 37.85 & & & & & & & 0.0 & LA & 37.85 \\
\hline Ikorodu Nth & 12.47 & & & & & & 12.47 & 0.0 & LA & 12.47 \\
\hline Imota & 7.8 & 1.0 & & 6.8 & & & & 0.2 & LA & 7.8 \\
\hline Igbogbo & 4.4 & 4.4 & & & & & & 0.0 & LA & 4.4 \\
\hline Total & 62.52 & 9.0 & & 10.8 & & 8.0 & 38.72 & 0.2 & & 62.52 \\
\hline$\%$ & & 14.39 & & 17.27 & & 12.79 & 61.93 & & & \\
\hline
\end{tabular}

Source: Authors' Field Survey 2019

Note: $C$ of $O=$ Certificate of Occupancy; this is the most highly rated and acceptable form of title to land; GCT = Governor's Consent; DAS= Deed of Assignment; EXC = Excision; $R C T=$ Receipt; $S V Y=$ Survey plan; $L O A=$ Letter of Allocation; NILL= Not Documented; QTY DEV= Quantity Developed; OG= Ogun; LA= Lagos

Table 3 further shows the extent of developers' contribution towards assuaging the housing deficit in the study area since 2004. While 249.15 hectares of land were acquired along the Lagos/Ibadan Expressway between 2004 and 2019, only 21.33 hectares (8.56\%) were used for housing construction. Similarly, in Lekki-Epe Expressway, only 14.17 hectares $(6.15 \%)$ out of the 230.37 hectares acquired were used for housing construction. In Ikorodu, 62.52 hectares were acquired with only $0.2(0.32 \%)$ hectares used for housing construction over same period. These results indicate that at least $90 \%$ of the acquired land in the study area was either not used at all or was used for other purposes than housing development.

\subsection{Barriers to Developers' Land Development for Housing Construction in Lagos Fringe Areas}

This section analyses developers' perceptions of the major barriers to housing development after land acquisition based on questionnaire responses. The developers' average ranking of the seriousness of 28 potential barriers identified from the literature on a scale of 1 to 5 are presented in Table 4 . Items with mean values of 4.0 and above were judged to be the major barriers to housing development in the study locations. Using this criterion, 9 of the 28 potential barriers were considered major barriers by the developers. Of these, 'High cost of building materials' was ranked as the most serious barrier affecting housing development (mean score of 4.40). Delay in title documentation ranked second (4.34) and weak mortgage system ranked third with a mean score of 4.33 . The most serious perceived barriers include financial, bureaucratic and local opposition problems. The developers did not perceive their own financial planning, market demand, construction delays, the physical site characteristics or labour costs as major barriers to housing development. Another barrier identified that was not listed on the questionnaire was 'Calls for regularisation of title after $C$ of $O$ '. This is a 
situation that occurs when there is a change in political regime. When this happens, all forms of development are put on hold and sometimes developers lose their land entirely.

\section{Table 4: Developers' Perceived Barriers Affecting Housing Development in Lagos Fringe Area}

\begin{tabular}{|l|c|c|}
\hline Potential Barriers & Mean & Rank \\
\hline High cost of building materials & 4.40 & 1 \\
\hline Title documentation delay & 4.34 & 2 \\
\hline Weak mortgage system & 4.33 & 3 \\
\hline Planning approval very slow and rigorous & 4.32 & 4 \\
\hline High interest rate/cost of borrowing & 4.19 & 5 \\
\hline Change in policy/ regulations & 4.12 & 6 \\
\hline Lack of coordination between various agencies & 4.11 & 7 \\
\hline Local opposition to fringe expansion & 4.07 & 8 \\
\hline Disturbance from local landowners & 4.04 & 9 \\
\hline Poor access to loan & 3.99 & 10 \\
\hline Complexity of the planning process & 3.98 & 11 \\
\hline Preservation of land for future sale & 3.98 & 11 \\
\hline High development tax on construction & 3.97 & 13 \\
\hline Changes in development charges & 3.93 & 14 \\
\hline Uncertainty about development policies & 3.83 & 15 \\
\hline Delay of government in installing infrastructure & 3.79 & 16 \\
\hline Unavailability of long-term loan & 3.79 & 16 \\
\hline $\begin{array}{l}\text { Lack of coordination between developers and government in } \\
\text { installing infrastructure }\end{array}$ & 3.72 & 18 \\
\hline $\begin{array}{l}\text { Limited scope for automatic approval of complying building } \\
\text { applications }\end{array}$ & 3.69 & 19 \\
\hline Uncertainty about planning standards & 3.64 & 20 \\
\hline Local opposition to high-density development & 3.60 & 21 \\
\hline Local opposition to urban expansion & 3.54 & 22 \\
\hline High labour wage & 3.44 & 23 \\
\hline Bad weather that delays or damages construction & 3.33 & 24 \\
\hline Land topography & 3.33 & 24 \\
\hline The land is not ripe for development & 3.30 & 26 \\
\hline Lack of effective demand & 3.29 & 27 \\
\hline Lack of cash flow planning for proper execution & 2.99 & 28 \\
\hline N & $\mathbf{1 0 9}$ & \\
\hline & & \\
\hline
\end{tabular}

To clarify what barriers to development are perceived, factor analysis was conducted to reduce and simplify the potential hindrances obtained from the literature into groups of hindrances. Suggested minimums for sample size in factor analysis include from 3 to 20 times the number of variables and absolute ranges from 100 to over 1000 (Mundfrom et al., 2005; De Winter et al., 2009). The data meet these criteria and are therefore suitable for factor analysis. The data validity and sampling consistency were tested further with 
the Kaiser-Meyer-Olkin (KMO) and Bartlett's tests. The KMO value is 0.76 with a significance of $\mathrm{p}=0.00$. When the $\mathrm{KMO}$ value is close to 1 , it denotes compactness in the pattern of correlations and factor analysis is judged reliable. A minimum value 0.6 is commonly accepted for this type of study (Hoque \& Awang, 2016).

Table 5 shows the rotated components that hinder housing development extracted by the factor analysis. The results indicate there are eight components that explain a total of $68.50 \%$ of the variance within the original variables. The reliability of the factors was tested using Cronbach's Alpha technique. The result produced a mean reliability coefficient of $0.898(90 \%)$ indicating that the factors are reliable and acceptable (DeVellis, 1991; Norusis, 2004). This can be interpreted as developers, in general, perceive eight general groups of hindrances that slow housing development in the Lagos fringe area. Only barriers with a loading of at least 0.5 were retained to provide a phrase that captures the commonality among the items as shown in Table 5. The identified group of barriers are described below.

Table 5: Rotated Component Matrix on the Causes of Delay in Housing Construction in Lagos Fringe Area

\begin{tabular}{|l|c|c|c|c|c|c|c|c|}
\hline \multirow{2}{*}{ Reason for delay in construction } & \multicolumn{7}{|c|}{ Components } \\
\hline & $\mathbf{1}$ & $\mathbf{2}$ & $\mathbf{3}$ & $\mathbf{4}$ & $\mathbf{5}$ & $\mathbf{6}$ & $\mathbf{7}$ & $\mathbf{8}$ \\
\hline Title documentation delay & 0.79 & & & & & & & \\
\hline $\begin{array}{l}\text { Planning approval very slow and } \\
\text { rigorous }\end{array}$ & 0.74 & & & & & & & \\
\hline Change in policy regulations & 0.59 & & & & & & & \\
\hline Complexity of the planning process & & 0.80 & & & & & & \\
\hline $\begin{array}{l}\text { Delay of government in installing } \\
\text { infrastructure }\end{array}$ & & 0.79 & & & & & & \\
\hline Change in development charges & & 0.65 & & & & & & \\
\hline $\begin{array}{l}\text { Lack of coordination between } \\
\text { various agencies }\end{array}$ & & 0.52 & & & & & & \\
\hline The land is not ripe for development & & & 0.79 & & & & & \\
\hline Lack of effective demand & & & 0.75 & & & & & \\
\hline $\begin{array}{l}\text { Local opposition to high-density } \\
\text { development }\end{array}$ & & & 0.70 & & & & & \\
\hline $\begin{array}{l}\text { Lack of cash flow planning for } \\
\text { proper execution }\end{array}$ & & & 0.68 & & & & & \\
\hline Unavailability of long-term loan & & & & 0.79 & & & & \\
\hline Poor access to loan & & & & 0.70 & & & & \\
\hline $\begin{array}{l}\text { Limited scope for automatic } \\
\text { approval of complying building } \\
\text { applications }\end{array}$ & & & & 0.59 & & & & \\
\hline Weak mortgage system & & & & 0.55 & & & & \\
\hline Land topography & & & & & 0.79 & & & \\
\hline $\begin{array}{l}\text { Bad weather that delays or damages } \\
\text { construction }\end{array}$ & & & & & 0.70 & & & \\
\hline High labour wage & & & & & 0.50 & & 0.51 & \\
\hline
\end{tabular}




\begin{tabular}{|l|l|l|l|l|l|l|l|l|}
\hline $\begin{array}{l}\text { Lack of coordination between } \\
\text { developers and government } \\
\text { institutions in installing } \\
\text { infrastructure }\end{array}$ & & & & & & & & \\
\hline Local opposition to urban expansion & & & & & & 0.69 & & \\
\hline Disturbance from local landowners & & & & & & 0.83 & & 0.69 \\
\hline High cost of building materials & & & & & & & 0.80 & \\
\hline High interest rate/cost of borrowing & & & & & & & 0.69 & \\
\hline $\begin{array}{l}\text { High development tax on } \\
\text { construction }\end{array}$ & & & & & & & 0.58 & \\
\hline $\begin{array}{l}\text { Local opposition to fringe } \\
\text { expansion }\end{array}$ & & & & & & & & 0.52 \\
\hline $\begin{array}{l}\text { Uncertainty about planning } \\
\text { standards }\end{array}$ & & & & & & & & 0.57 \\
\hline $\begin{array}{l}\text { Rotated sums of squared loadings } \\
\text { (\% Variance) }\end{array}$ & $\mathbf{1 0 . 9 5}$ & $\mathbf{1 0 . 3 8}$ & $\mathbf{8 . 5 9}$ & $\mathbf{8 . 5 3}$ & $\mathbf{8 . 0 4}$ & $\mathbf{7 . 4 2}$ & $\mathbf{7 . 3 9}$ & $\mathbf{7 . 1 9}$ \\
\hline
\end{tabular}

Notes: Extraction Method: Principal Component Analysis. Rotation Converged in 20 iterations. Rotation Method: Varimax with Kaiser Normalisation. Total Variance explained $65.50 \%$. Kaiser-Meyer-Olkin Measure of Sampling adequacy $=0.76 ; d f=406.00$. Bartlett's Test of Sphericity=1562.677; Sig.0.00.

The first theme is named 'Institutional' and explains $10.95 \%$ of the total variance among the variables. Variables loading on this barrier are: planning approval very slow and rigorous, title documentation delay and change in policy/regulations. Strengthening land institutions and frameworks is long overdue to provide support for developers. The needs include secure title support and obtaining building permits/approval. Secure title to land is regarded as crucial because of its profound effect on the working of land and capital markets. Therefore, there is a need for land institutions to be able to define, document, record, and enforce property rights and changes in a way that is transparent and accessible.

The second theme is named 'Inconsistency in government policy and regulations' and explains $10.38 \%$ of the total variance. Variables loaded on this barrier are: the complexity of the planning process, delay of government in installing infrastructure, change in development charges and lack of coordination between various agencies. Many times, due to political instability and the various land agencies in the study location, some overlapping policies on land exist that negate the developers' efforts in housing development. These agencies need to be merged and unified to enhance sustainable policy to control and regulate the fringe development.

The third theme is named 'Lack of effective demand and land not ripe for development'. Variables loading on this barrier are: a lack of effective demand, land not ripe for development, local opposition to high-density development and lack of planning cash flow before execution. Most of the time, governments are saddled with the responsibility of providing infrastructure such as electricity, water, drainage, and sewage system to enhance planned development. Unfortunately, these fringe areas lack the requisite infrastructure, therefore the land is seen as unfit for development. 
The government should make an effort to provide adequate infrastructure through an infrastructure development schemes or funding agencies.

The fourth theme is named 'Finance'. Variables loading on this barrier are: weak mortgage systems, poor access to loans, unavailability of long-term loans and limited scope of automatic approval of complying building applications. Mass housing development is almost impossible without funding (Nubi, 2000). Lack of a mortgage system has been a bane to the housing sector in the study area. Therefore, a need exists to build a mortgage system that can support the housing sector.

The fifth theme is named 'Climate change'. The two variables with the highest loadings on this barrier are land topography and bad weather that delays or damage construction. High labour wage carries a smaller coefficient and is better related to factor seven on which it also loads. Climatic change revolves around topography and climatic conditions such as the seasonal flooding in the study areas, which hamper development and increases the cost of construction.

The sixth theme is named 'Lack of coordination between government agencies and developers in infrastructure provision'. The two variables loading highest on this barrier are lack of coordination between various agencies and lack of coordination between developers and government institutions. Local opposition to high-density development contributes less strongly to this factor. Lack of coordination has resulted in conflicts between developers and the government in charge of the regulatory mechanism in the study area. Unfortunately, most governments have found it difficult to address this barrier.

The seventh theme is named 'High cost of construction'. Variables loading on this barrier are: high labour wage, high cost of building materials, highinterest rate/cost of borrowing and weak mortgage system. Policies to encourage industrialisation of local building materials are lacking, resulting in high cost of building materials and the inadequacy of manpower in the construction industry.

The eighth theme is named 'Opposition to fringe expansion from local landowners'. Variables loading on this barrier are: disturbance from local landowners, local opposition to fringe expansion and uncertainty about planning standard. This shows up in the form of lack of trust in government policy and policy mismatch among the various agencies. A coordinated and innovative approach towards making a uniform policy to enhance development and growth of the community is long overdue.

Game theory postulates action and reaction between two or more actors. In this study, the developers acquired land for housing development while government lacks activation strategies to promote development. This has led to various challenges, resulting in strategy mismatch, causing conflicts 
between actors and bureaucratic bottlenecks that hamper housing development.

This study shows that challenges relating to the institutional framework (complexity of the planning process, difficulty of obtaining planning approval, title documentation delay) and inconsistency in government policy and regulations as well as lack of coordination within agencies and with developers are major impediments to housing development. Costs (labour, building materials, interest, tax) and unavailability or lack of access to loans are another source of concern. Seeking funding through financial institutions or alternative sources requires an acceptable title document ( $\mathrm{C}$ of O) or GCT.

This study's findings affirm Chatterjee's (1981) study where he identified organisational inefficiencies and housing policy framework as propellant factors germane to new housing development. This is still critically important after almost four decades and is yet to be substantially addressed to enhance housing development initiatives of developers in the study areas. As a result, urgent attention is needed to address the issue. Also, further knowledge is needed about strategies for promoting local building materials for construction rather than importation while ensuring efficient land use policy in the fringe areas. In addition, there is a need to ensure provision of basic infrastructure while providing finance to enhance the enormous untapped revenue-generating potential and promote housing development.

\subsection{Identification of Strategies to Increase Housing Development}

To identify differences between strategies considered important by developers and those adopted by the government, opinions of both were collected and compared.

\subsubsection{Developers' Preferences of Strategies to Increase Housing Development}

Developers' opinions were sought as to what they perceived to be policy approaches that can help increase housing development on acquired land. They were asked to rate the identified strategies on a scale of 1 to 5 from 'Very unacceptable' to 'Very acceptable'. The mean ranking of all the six strategies are greater than 4.0 (as shown in Table 6), implying that the respondents accept that if adopted, these strategies will enhance housing development. Specifically, the strategies are: (1) adoption of public-private joint ventures in real estate investment, (2) decentralisation of land administration, (3) introduction of collaborative housing production policy, (4) collaborative financing, (5) provision of land free of charge and (6) provision of tax holiday. Provision of infrastructure was also specified by some of the respondents as another strategy needed to boost housing development. 


\section{Table 6: Developers' Preferred Strategies that can Encourage} Increased Housing Development

\begin{tabular}{|l|c|c|c|}
\hline Strategy & Mean & $\begin{array}{c}\text { Std. } \\
\text { Deviation }\end{array}$ & Rank \\
\hline $\begin{array}{l}\text { Joint venture in real estate investment between public and } \\
\text { private sector agencies. }\end{array}$ & 4.69 & 0.55607 & 1 \\
\hline $\begin{array}{l}\text { Decentralisation of land administration to ease the complex } \\
\text { system of both enforcements of regulations and regulatory } \\
\text { processes }\end{array}$ & 4.51 & 0.70204 & 2 \\
\hline Collaborative housing production policy enactment & 4.49 & 0.83461 & 3 \\
\hline $\begin{array}{l}\text { Availability of collaborative financing to encourage urban } \\
\text { fringe development }\end{array}$ & 4.42 & 0.74899 & 4 \\
\hline Provision of tax subsidy e.g. provision of land free of charge & 4.40 & 0.8167 & 5 \\
\hline Provision of tax holiday & 4.24 & 0.83776 & 6 \\
\hline
\end{tabular}

Developers were asked to list strategies they would prefer to be adopted to motivate them to invest more in mass housing development. As shown in Table 7, 25.7\% considered availability of land and access to housing development loans are of critical importance to motivate investment while an overwhelming majority of $62.4 \%$ believed that joint venture between government and developers in policy formulation would be a significant motivation for housing development in the Lagos fringe area.

Table 7: Developers' Preferred Strategy for Housing Development

\begin{tabular}{|l|c|}
\hline Strategy & Frequency \\
\hline Joint venture/collaboration in policy formulation & 68 \\
\hline Both land availability and access to housing loan & 28 \\
\hline Land availability & 10 \\
\hline Favourable policy on building materials cost, labour cost & 2 \\
\hline Indifference & 1 \\
\hline Total & $\mathbf{1 0 9}$ \\
\hline
\end{tabular}

\subsubsection{Land Bureau Officers' Perspective on Housing Development Strategies}

Developers' preferred strategies were compared with those of government officials to identify common positions, if any, among the stakeholders on strategies that could encourage increased development of housing units. When asked about what policies are in place to enhance immediate housing development on land acquired in the fringe areas, $32.0 \%$ of the Land Bureau officials mentioned that the conditional clause that acquired land must be developed within two years of being issued a $\mathrm{C}$ of $\mathrm{O}$ is a major strategy for encouraging housing development and $19.0 \%$ indicated that the development of the housing scheme/urban physical planning initiative is being used, as shown in Table 8 . This does not show that the Land Bureau has a clear policy or strategy to collaborate with developers in the fringe areas. 
Table 8: Policies for Immediate Housing Development

\begin{tabular}{|l|c|}
\hline Policy & Frequency \\
\hline $\begin{array}{l}\text { Conditional clause for not developing acquired land within } 2 \\
\text { years in C of O }\end{array}$ & 10 \\
\hline $\begin{array}{l}\text { Development of housing scheme initiative/ Urban physical } \\
\text { planning initiative }\end{array}$ & 6 \\
\hline Provision of master plan & 13 \\
\hline No answer & $\mathbf{3 1}$ \\
\hline Total & 2 \\
\hline
\end{tabular}

The conditional clause was the most common policy and the preferred strategy. This means that a punishment clause is preferred and being used rather than collaboration. This is also evidenced in Table 9 where all but one potential collaborative synergies were reported as not being used often. The Land Bureau officers were asked to rate the extent to which seven collaborative strategies are being used to enhance immediate housing development of land acquired in the fringe areas. A scale of 1 to 5 was used (5= 'Very often', 4= 'Often', 3= 'Sometimes', 2= 'Rarely', 1= 'Not in existence'). The results reveal that there is little or no collaborative synergy between the government and REDAN in the fringe areas. Collaboration with secondary stakeholders (individual landowners) was ranked most common. This shows the weak synergy that exists between REDAN and government agencies, resulting in conflicting views of the parties in the management and development of the fringe areas.

Table 9: Government Collaborative Synergy to Enhance Immediate Housing Development on Land Acquired in the Urban Fringe

\begin{tabular}{|l|c|c|c|}
\hline Government Collaborative Synergy & Mean & Std. Deviation & Rank \\
\hline $\begin{array}{l}\text { Collaboration with secondary stakeholders } \\
\text { (Individual Landowners) }\end{array}$ & 3.74 & 1.389 & 1 \\
\hline Collaboration with Financial Institutions & 3.48 & 1.261 & 2 \\
\hline $\begin{array}{l}\text { Collaboration with Housing Finance } \\
\text { Organisation }\end{array}$ & 3.48 & 1.235 & 2 \\
\hline $\begin{array}{l}\text { Collaboration with the Built Industry } \\
\text { Professionals }\end{array}$ & 3.38 & 1.308 & 4 \\
\hline $\begin{array}{l}\text { Collaboration with Housing Association/ } \\
\text { REDAN }\end{array}$ & 3.29 & 1.442 & 5 \\
\hline Inter government Collaboration & 2.96 & 0.406 & 6 \\
\hline $\begin{array}{l}\text { Collaboration with Residents' } \\
\text { Organisation/Association }\end{array}$ & 2.94 & 1.365 & 7 \\
\hline
\end{tabular}

Note: $N=31$.

Table 10 depicts a list of strategies the 31 Land Bureau officers would prefer government put in place. The results suggest the need for creating awareness of sustainable strategies to enhance housing development through capacity building. The fact that over $25 \%$ of the respondents are indifferent to the 
strategies adopted in their various departments shows the need for human capacity re-engineering.

\section{Table 10: Land Officers' Preferred Strategies for Fostering Housing Development in the Lagos Fringe Area}

\begin{tabular}{|l|c|}
\hline Strategy & Frequency \\
\hline $\begin{array}{l}\text { Conditional clause in the C of O that land must be developed within } 2 \\
\text { years }\end{array}$ & 15 \\
\hline Appraisal of construction plan in line with financial capability & 3 \\
\hline Prompt granting of development permit & 2 \\
\hline Provision of infrastructural facilities & 3 \\
\hline Indifference & 8 \\
\hline Total & $\mathbf{3 1}$ \\
\hline
\end{tabular}

Further, the officials were asked to indicate other general options they would like to suggest for the immediate development of land acquired in the fringe areas. As shown in Table 11, there was no overwhelming consensus. A majority of $61.3 \%$ (19) were unable to suggest any option that could be employed. Four suggested that sales agreements should be duly registered in court to ensure adherence to the development period and another four indicated provision of inter government policy as a suggested strategy. This clearly shows that Land Bureau officials either lack suggestions or do not care about strategies to foster immediate housing development.

\section{Table 11: Land Officers' Suggestions for Other Strategies for Encouraging Immediate Development of Land Acquired in the Lagos Fringe Area}

\begin{tabular}{|l|c|}
\hline Strategy & Frequency \\
\hline No response & 19 \\
\hline Sales agreement duly registered in court to enforce development period & 4 \\
\hline Provision of inter government policy & 4 \\
\hline Appraisal of the financial capability prior to the allocation of land & 2 \\
\hline Provision of infrastructure facilities & 2 \\
\hline Total & $\mathbf{3 1}$ \\
\hline
\end{tabular}

The analysis shows that the current strategies focus on control of developers if they do not act to construct housing soon after acquiring land. When Land Bureau officials were asked to suggest options that can foster immediate development of land acquired, the majority had no suggestions whereas developers indicated preference for joint ventures with relevant agencies on housing investments policy and infrastructure development. This signifies developers' preference for inclusion in the policymaking process as this will enhance ease of acceptability and adoption as well as conflict reduction between developers and government agencies on land matters. Yates (2011), Iyanda (2015), La Cava (2016) and Wubneh (2018) affirm that when these strategies are not considered, development of housing units suffers significant 
delay. This implies that appropriate partnerships around institutional framework and infrastructure development will help remove the most serious barriers to development that the developers identified in the Lagos fringe area.

\section{Conclusion and Recommendation}

The players and actors in this study are the developers and key Land Bureau officials. The developers start the process through land acquisitions and initiating development plans towards obtaining appropriate documents $(\mathrm{C}$ of $\mathrm{O})$ to secure their rights. Developers are dominant in the fringe areas in the sense that they often initiate projects through opening up access routes, motivated by maximising financial profit. However, despite ample evidence of demand for housing in the Lagos fringe areas, the study shows that only about $10 \%$ of the land acquired in the study areas for housing since 2004 has been developed despite government incentive policies promoting land titling and documentation. It is evident that bureaucratic bottlenecks in administration have set back policy implementation. Generally, government has been more reactive, that is, responding to developers' land acquisition initiatives rather than being proactive. Government strategies are seen by developers as grossly inadequate for enhancing housing development. Moreover, the policies adopted by government are at variance with developers' perceptions and expectations of what is necessary. This seems to be the major setback for adequate housing development on land acquired by developers in the fringe areas.

More strategic actions are recommended in the form of collaborative efforts and policy interventions through the introduction of a Housing Development Act (HDA) to provide legislative backing for suggested improvement strategies. This will resolve conflicts amongst stakeholders as well as unstable and ineffective policy response in the fringe areas. Also, there is need for decentralisation of land administration processes to ease the complex system developers currently need to navigate in order to achieve their housing investment aspirations. If Land Bureau agencies are decentralised at the local government level, it will create more awareness and better understanding of policies. This suggestion assumes that local governments can be empowered to control these activities. However, this proposal may be unrealistic because the local governments currently seem uncoordinated and are still struggling for autonomy. As such, if coordinated and effective measures are to be undertaken on urban fringe growth, then there may be a need to use or create an Urban Fringe Development Control Agency (UFDCA) with powers to control the fringes, overseeing land acquisitions and development until local governments have the capacity to effectively do so. Such powers could have a limited time duration, with the agency being dissolved once an area is reasonably well developed. Further, there is need for careful enforcement of appropriate regulations and regulatory processes. The government-adopted strategy of applying the forfeiture clause to ensure quick housing development must be harmonised with the developers' expectations of 
collaborative housing strategies through infrastructure provision to enhance fringe area development.

\section{References}

Adedire, F.M. (2018). Peri-urban Expansion in Ikorodu, Lagos: Extent, Causes, Effects, and Policy Response. Urban Forum, 29(3), pp.259275.

Adedire, F.M., Oduwaye, L. \& Tony, I. (2016). Drivers of housing development in Ibeju-Lekki, Lagos peri-urban settlement. International Journal of Innovative Research and Advanced Studies, 3(10), pp.200-205.

Adedayo V. (2014). Potentials and contributions of urban and peri-urban agriculture to the Lagos megacity region. Journal of Agriculture and Sustainability, 5(2), pp.171-187.

Adelekan, I. (2013). Private sector investment decisions in building and construction: Increasing, managing and transferring risks: Case study of Lagos, Nigeria. Background paper presented at the global assessment report on disaster risk reduction. Geneva, Switzerland. [Online]. Available at: https://www.preventionweb.net/english/hyogo/gar/2013/en/bgdocs/ Adelekan, \%202012.pdf. Accessed: $28^{\text {th }}$ April, 2018.

Ademiluyi, I.A. \& Bashiru A.R. (2008). Public and Private Developers as Agents in Urban Housing Delivery in Sub-Saharan Africa: The Situation in Lagos State. Humanity \& Social Sciences Journal 3(2), pp.143-150.

Adisa, W. B. (2020). Land use policy and urban sprawl in Nigeria: Land use and the emergence of urban sprawl. In M. Khosrow-Pour, S. Clarke, M.E. Jennex \& A. Anttiroiko, (eds), Megacities and Rapid Urbanization: Breakthroughs in Research and Practice. Hershey, USA: International Management Association. pp.331-349.

Agbola, S.B. (1993). Major problems of housing in Nigeria. In proceedings of a workshop on housing problems in Nigeria. Ibadan, Nigeria. December, 1993.

Akeju, A.A. (2007). Challenges to Providing Affordable Housing in Nigeria. In proceedings of the 2nd Emerging Urban Africa International Conference on Housing Finance. Abuja, Nigeria. October 17-19, 2007.

Akinyode B.F. \& Tareef, H.K. (2014). Bridging the gap between housing demand and housing supply in Nigerian urban centres: A review of government intervention so far. British Journal of Arts and Social Sciences, 18(11), pp.94-107.

Allen, A. (2003). Environmental planning and management of the peri-urban interface: perspectives on an emerging field. Environment and Urbanization, 15(1), pp.135-148.

Aliu, I.R., Towry-Coker, L. \& Odumosu, T. (2017). Housing policy debacle in Sub-Saharan Africa: an appraisal of three housing programs in 
Lagos Nigeria. African Geographical Review, pp.1-19. DOI:10.1080/19376812.2017.1284005.

Alufohai, A.G. (2013). The Lagos State 2010 Mortgage Law and the Supply of Housing. In proceedings of the International Federation of Surveyors FIG Working Week- Environment for Sustainability. Abuja, Nigeria. $5^{\text {th }}$ May, 2013.

Anglin, P.M. \& Arnott, R. (1991). Residential real estate brokerage as a principal agent problem. Journal of Real Estate Finance and Economics, 4, pp.99-125.

Babalola, O.D., Ibem, E.O., Olotuah, A.O., Opoko, A.P., Adewale, B.A. \& Fulani, O.A. (2020). Housing quality and its predictors in public residential estates in Lagos, Nigeria. Environment, Development and Sustainability. 22(5), pp.3973-4005.

Ball, M. (2003). Markets and the structure of the house building industry: An international perspective. Urban Studies, 40, pp.897-916.

Chatterjee, L. (1981). Housing development in Nigeria. Agency for International Development, Office of Housing.

Dasgupta, B., Lall, S.V. \& Lozano-Gracia, N. (2014). Urbanization and Housing Investment. World Bank Policy Research Working Papers. [Online]. Available at:

https://elibrary.worldbank.org/doi/abs/10.1596/1813-9450-7110. Accessed: 20 $0^{\text {th }}$ June, 2015.

De Maria, M. (2019). Understanding land in the context of large-scale land acquisitions: A brief history of land in economics, Land, 8(1), 15. DOI:10.3390/land8010015.

De Winter, J.C.F., Dodou, D. \& Wieringa, P.A. (2009). Exploratory factor Analysis with small sample sizes. Multivariate Behavioral Research, 44(2), pp.147-181.

DeVellis, R.F. (1991). Scale Development: Theory and applications. Newbury Park: Sage Publications, Inc.

Feng, L., Du, P., Zhu, L., Luo, J. \& Adaku, E. (2015). Investigating Sprawl Along China's Urban Fringe from a Spatio-Temporal Perspective. Applied Spatial Analysis and Policy, 9, pp.1-18.

Gallent, N. (2006). The Rural-Urban fringe: A new priority for planning policy? Planning Practice and Research, 21(3), pp.383-393.

Gant, R.L., Robinson, G.M. \& Fazal, S. (2011). Land-use change in the "edgelands": Policies and pressures in London's rural-urban fringe. Land Use Policy, 28(1), pp.266-279.

Heimlich, R. \& Anderson, W. (2001). Development at the Urban Fringe and Beyond: Impacts on Agriculture and Rural Land- United States Department of Agriculture. Agricultural Economic Report No. 803.

Hoque, A.S.M.M. \& Awang, Z. (2016). The Exploratory Factor Analysis (EFA) of Entrepreneurial Marketing Scale-Development and Validation. In Proceedings of The Tourism Conference. Terengganu, UniSZA. April, 2016. pp.20-22.

Holtslag-Broekhof, S.M., Beunen, R., van-Marwijk, R. \& Wiskerke, J.S.C. (2014). "Lets' try to get the best out of it" Understanding land transaction during land use change. Land Use Policy, 41, pp.561-570. 
Hsieh, C. \& Moretti, E. (2017). Housing constraints and spatial misallocation, NBER Working Paper Series.

Hull, M. \& McGroarty, F. (2014). Do emerging markets become more efficient as they develop? Long memory persistence in equity indices. Emerging Markets Review, 18, pp.45-61.

IMF. (2015). International Monetary Fund Report. Annual Report of the Executive Board. [Online]. Available at: https://doi.org/10.5089/9781475544886.011. Accessed: $20^{\text {th }}$ May, 2020.

Iyanda, B.A. (2015). Formal land ownership and housing development in Lagos State, Nigeria. Asian Journal of Science and Technology 6(3), pp.1155-1160.

La Cava, G. (2016). Housing prices, mortgage interest rates and the rising share of capital in the United States. BIS Working Papers, No. 572.

Mabogunje, A.L. (1993). New paradigm for urban development in Africa. In proceedings of The Annual Conference of the Canadian Association of African Studies. Toronto, Canada. 12-15 ${ }^{\text {th }}$ May, 1993.

Mabogunje A.L. (2007). Developing mega cities in developing countries. Lecture delivered at a colloquium organized by the graduating class, Department of Geography. Lagos, Nigeria. 12 ${ }^{\text {th }}$ September, 2007.

Manda, S., Tallontire, A. \& Dougill, A.J. (2019). Large-scale land acquisitions and institutions: patterns, influence and barriers in Zambia. The Geographical Journal, pp.1-15.

Maruani, T. \& Amit-Cohen, I. (2011). Characteristics of developers and their relations to open space conservation. Land Use Policy, 28, pp.887897.

Morakinyo, K.O., Okunola, A.S., Ogunrayewa, M.O. \& Dada, O. (2015). A review of private sectors' involvement in urban housing provision in Nigeria. International Journal of Civil Engineering, Construction and Estate Management, 3(2), pp.36-47.

Mori H. (1998). Land Conversion in the urban fringe: Comparative Study of Japan, Britain and the Netherlands. Urban Studies, 35(9), pp.15411558.

Mundfrom, D.J., Shaw, D.G. \& Ke, T.L. (2005). Minimum Sample Size Recommendations for Conducting Factor Analyses. International Journal of Testing, 5(2), pp.159-168.

National Housing Policy (NHP). (2004). Draft Housing Policy. Abuja: Federal Republic of Nigeria.

Norusis, M. (2004). SPSS 13.0 Guide to Data Analysis. Upper Saddle-River, N.J: Prentice Hall, Inc.

Nubi, T.O. (2000). Housing finance in Nigeria- need for re-engineering. In proceedings at The Ideal Habitat Cooperative Housing Initiatives Seminar. Abuja, Nigeria. $18^{\text {th }}$ July, 2000.

Nubi, T.O. (2001). Housing production through site and services scheme: The Nigeria Experience. Lagos Journal of Environmental Studies, 1, pp.44-45.

Nubi, T.O. (2015). Beyond bricks and mortar. An inaugural lecture, Department of Estate Management, University of Lagos. Lagos: University of Lagos press. 
Nwoko, K.C. (2016). Land ownership versus development in the era of globalisation: A trajectory of conflict and wealth accumulation in southern Nigeria. Journal of African Transformation, 1(2), pp.77-94.

Ogu, V.I. \& Ogbuozobe, J.E. (2001). Housing policy in Nigeria: towards enablement of private housing development. Habitat International, 25(4), pp.473-492.

Olmedo, C. \& Ward, P.M. (2016). Model subdivision: The new face of developer lot sales for low-income Colonia-type housing in Texas. Land Use Policy, 52, pp.181-194.

Olofa, S. \& Nwosu, A. (2015). Investigating the problems associated with public private partnership in the process of housing delivery in Nigeria. International Journal of Education and Research, 3(1), pp.123-130.

Omirin, M.M. (1992). Land for Private Low-Income Earners. An evaluation of the effect of Land Nationalization. Unpublished Ph.D. Thesis, University of Cambridge.

Onibokun, A.G. (1990). A review of government housing policy and programme. In Onibokun, A. G. (Eds), Urban Housing in Nigeria. Ibadan: Nigerian Institute of Social and Economic Research (NISER). Ibadan, pp.1-16.

SACN. (2018). Financing Spatial Transformation. State of City Finances Report, pp.66-86. [Online] Available at:

http://www.ukesa.info/download/aDHbc9xZ0zOCg8PvAoMhdGFq W26iVREr/SACN 2018 SoCF IV.pdf. Accessed on: $20^{\text {th }}$ February, 2021.

Saxena, A.M. \& Vyas, S. (2019a). Peri urban development in developing countries. International Journal of Civil Engineering and Technology 10(1), pp.2124-2133.

Saxena, A.M. \& Vyas, S. (2019b). Peri-urban Areas, Sustainability Dimensions. International Journal of Mechanical and Production Engineering Research and Development. 9(2), pp.545-554.

Samsura, D.A.A., van der Krabben, E. \& van Deemen, A.M.A. (2010). A game theory approach to the analysis of land and property development processes. Land Use Policy, 27(2), pp.564-578.

Sengupta, U. (2013). Inclusive development? A state-led land development model in New Town, Kolkata. Environment and Planning $C$, Government and Policy, 31(2), pp.357-376. DOI:10.1068/c1103.

UNDESA. (2019). World Population Prospects 2019. [Online] Available at: http://creativecommons.org/licenses/by/3.0/igo/. Accessed on: $22^{\text {nd }}$ August, 2021.

Usoro, U. (2015). Effectiveness of sites and services schemes in low and medium income housing provision in Nigeria. International Journal of Economic Development Research and Investment, 6(2), pp.39-50.

World Bank. (2015). Stocktaking of the Housing Sector in Sub-Saharan Africa. Washington DC: The International Bank for Reconstruction and Development/ The World Bank. pp.1-23.

Wubneh, M. (2018). Policies and praxis of land acquisition, use and development in Ethiopia. Land Use Policy, 73, pp.170-183. 
Yates, J. (2011). Housing in Australia in the 2000s: On the agenda too late? In H. Gerard and J. Kearns (Eds), The Australian Economy in the 2000s proceedings of a Conference, Reserve Bank of Australia. Sydney. pp.261-296.

Yin, R.K. (2011). Qualitative Research from start to finish. New York: The Guiliford Press.

Zhang, X., Bao, H. \& Skitmore, M. (2015). The land hoarding and land inspection dilemma in China: An evolutionary game theoretic perspective. Habitat International, 46, pp.187-195. 